ORIGINAL ARTICLE

\title{
Validity and reliability of the GHI-SN as an alternative indicator to describe health inequities among children under five in Indonesia's sub-national level
}

\author{
INA KUSRINI ${ }^{1 *}$, SRI SUPADMI ${ }^{1}$, DONNY KRISTANTO MULYANTORO ${ }^{1}$, AGUNG DWI LAKSONO $^{2}$, KRISTINA L TOBING $^{3}$ \\ ${ }^{1}$ National Institute of Health Research And Development, Ministry of Health Unit in Magelang, \\ ${ }^{2}$ National Institute of Health Research And Development, Ministry of Health, Humaniora and Empowerment, and Health Policy Center \\ ${ }^{3}$ National Institute of Health Research And Development, Ministry of Health, Public Health Effort \\ ${ }^{*}$ Corresponding Author: Ina Kusrini, SKM, MKM ( Master of Public Health), National Institute Health Research Development Ministry of \\ Health, Unit in Magelang, Jln. Kapling Jayan Borobudur Magelang, + 62293789435 (telephone number ) ; +62293 788460, Email: \\ dyy_syg@yahoo.com
}

\begin{abstract}
The subnational global hunger index (GHI-SN) is derived from the global hunger index as a simple indicator to compare hunger status at each subnational level and monitor health program achievement concerning the global target. The purpose of this objective study is to ensure the validity and reliability of the subnational global hunger index; to assess health inequality in children under the age of five in Indonesia.

Method: We use secondary data analysis to determine malnutrition and child mortality prevalence using aggregate data from national basic health research survey reports $(2007,2010,2013,2018)$ and demographic survey reports from 2002, 2012, and 2017. The subnational hunger index was calculated using previously standardized undernutrition, stunting, wasting, and child mortality rates. Factor analysis and Pearson correlation with Alpha Cronbach coefficient were used to assess the validity and reliability. Further analysis using longitudinal panel data analysis with random effect models in STATA.

Results: The total percentage of variance $(56.32 \%)$ demonstrates indicator construct validity. Cronbach Alpha Coefisien $>0.90$, according to reliability analysis. Pearson correlation between GHI-SN and Public Health Development Index (IPKM) for all and IPKM for children under five (IPKM) 2013 and 2018 and IKPS (Special Index Stunting Management) index is strong, with $r:-0.8:-0.67$, respectively.

Conclusion: The study found the Subnational Global Hunger Index (GHI-SN) to be valid and reliable. It can be used as an alternative measurement tool in Indonesia to assess health inequality and hunger in children under five.

Keyword: Children under five, GHI, Subnational hunger index
\end{abstract}

\section{INTRODUCTION}

Malnutrition in children under the age of five is the world's most serious public health problem. Recent national surveys in most countries reveal a high prevalence of undernutrition, which has decreased only slightly over the last decade. Otherwise, obesity and related diseases are increasing in prevalence ${ }^{1}$. In developing countries, 88 percent (124 countries out of 141) have malnourished children under five, and 29 percent (41 countries) have severe malnutrition. The global prevalence of malnutrition in children under the age of five is 3.62 percent, or 15.95 million stunted and wasted children, while 1.87 percent of children under the age of five, or 8.23 million, increase in stunting and overweight ${ }^{2}$.

However, the World Health Organization (WHO) reports that hunger and malnutrition are major threats to global health. Hunger is characterized by an inability to obtain an adequate intake of the daily minimum dietary energy requirement ${ }^{3}$. Hunger is a result of a relationship with poverty and an unhealthy environment. According to Wiesmann et al. l's concepts of hunger, it is described in four indicators: prevalence of stunting, which reflects chronic undernutrition, and prevalence of wasting, which reflects acute undernutrition. Children undernourishment due to insufficient caloric intake and child mortality reflect a fatal combination of inadequate nutrition and an unhealthy environment; GHI Scores were calculated ${ }^{4}$.
The GHI score is one of several comprehensive measurement tools designed to represent hunger and undernutrition on a global, regional, and national scale. The most recent $\mathrm{GHI}$ score revealed that global hunger decreased from 29.2 to 20.9 in 2017, still classified as severe. The GHI scores differed by region. The majority of Asian countries have a GHI score of moderate to severe hunger. It means that undernutrition among children is still a major public health issue in some developing countries ${ }^{4}$.

The National GHI score 2017 classified Indonesia as having a serious hunger level, but it only represents hunger at the national level. According to basic health research, the proportion of malnutrition and underweight status in children under the age of five was 17.7 percent, the proportion of stunting was 30.8 percent, and the proportion of wasting was 10.2 percent (Riskesdas) ${ }^{5}$. While there is a disparity in nutrition status related to ecological variations.

Furthermore, the country used the decentralization approach to monitor and control the health program. As a result, tools for measuring health program achievement output at the sub-national and district levels are required ${ }^{6}$. The purpose of this study is to evaluate the validity and reliability of the global hunger index at the sub-national level in describing the health inequality status of children underfive in Indonesia. 


\section{MATERIALS AND METHODS}

Research design: This study used secondary data analysis using aggregate data from combination results of two cross-sectional surveys; the national basic health research survey report ( Riskesdas) in 2007, 2010, 2013, 2018, and the demographic health survey in 2002, 2012, 2013 (DHS). Both surveys was conducted in 541 districts and 34 provinces of Indonesia to represent national and regional health status in population with a multistage cluster sampling method.

Population and sample research: The population of this study was all data of the household that was reported in Riskesdas or DHS surveys. The sample was a household that has children under five, measure high and weight and was calculated of nutrition status prevalence in each province as a sub-national level.

Collection / research stages: We get aggregate data on the prevalence of nutrition status in a series of times from the Riskesdas report in 2007, 2010, 2013 and 2018 The child mortality rate was obtained from the DHS survey report in 2002, 2012 and $2017^{9}$. Entry and cleaning data was done before analysis. Compute index composite using the $\mathrm{GHI}$ calculation index. Then, we measure the validity and reliability of the index. Estimate the relationship with another index. Further analysis to assess the determinant factors that related to the index.

Data analysis: We calculated an index using licensed SPSS 21 from National Institute Health Research and Development unit in Magelang. The GHI-SN score was calculated and adapted from the Global Hunger index calculation method that was performed in 3 dimensions and 4 indicators, whereas using three steps process. The first, we draw from available data to capture the multidimensional nature of hunger. They are the prevalence of stunting, wasting, undernourishment and child mortality at each sub-national level. Second, all prevalence was standardized with denominators that were used in a global standard. Based on the highest observed level for the indicator on global scales in recent decades ${ }^{4}$. Third standardized scores are aggregate to be GHI -SN score.

Each dimension of the $\mathrm{GHI}$ component contributes to equal $1 / 3$ of the score. The inadequate food supply that was represented by children undernourishment (PUN), child undernutrition that was performed by stunting and wasting, child mortality that was performed by children under-five mortality (CMR). Stunting (CST) and wasting (CWA) contribute equally to weight $1 / 6$ of the score. This three-step process results in $\mathrm{GHI}$ Score sub-national ranging from $0-100,100$ reflect zero hunger and show the severity of hunger in line with decrease score of GHI -SN ${ }^{4}$.

The denominator that was used to standardized score in each indicator based on a threshold set slightly above the highest prevalence of each indicator observed in worldwide 1998-2013. The highest prevalence of undernourishment ( PUN) worldwide is 76.5. So the denominator is 80 , the denominator for stunting based on highest prevalence is 70 , the denominator of wasting based on highest prevalence is 30 , the denominator of child mortality is 35 . The aggregate score is the prevalence of each indicator divide into a standardized denominator and multiplication with weight. The summarize of $\mathrm{GHI}$ score method shown in the equation below ${ }^{4}$.

GHI score : $(1 / 3 \times$ PUN/ $80 \times 100+1 / 6 \times$ CWA $/ 30 \times 100+$ $1 / 6 \times$ CST/70 $\times 100+1 / 3 \times$ CMR/35x100)

GHI SN scores describe the level of hunger in each province in Indonesia. Validity construct by factor analysis was calculated to shows the percentage of variants contribute to a composite index ${ }^{10-12}$. Reliability analysis by time using Cronbach Alpha Koefisien, whereas > 0,6 shows that this instrument reliable. GHI-SN score was analyzed by a parametric Pearson correlation to a similar index that was used previously and has a complicated variable.

IPKM ( Public Health Development Index) is an index to describe health status in Indonesia that was performed in 30 indicator and divide into 7 sub index : (1) Health status in children under five sub index that was performed by 6 indicator ( Proportion of stunting, proportion of wasting, , proportion of overweight, frequency of measurement of weight during last 12 month until survey was conducted, neonatal visited program, complete of immunization ); (2) Reproduction health sub index that was performed by 3 indicator (using contraceptive method, pregnancy antenatal care, proportion of chronic energy malnutrition in women of childbearing) ; (3) Health service sub index that was performed by 5 indicator (delivery birth in health center with medical staff, ratio of doctor in sub district level, ratio of integrated service center (posyandu) in village level, ration midwife in village level,health assurance proportion in village level); (4)Health behavior sub index that was performed by 5 indicator (smoking behavior, hand washing behavior, open defecation free, physical activity, teeth brush activity) ; (5) Non communicable disease sub index that was performed by 6 indicator ( hipertention, injury, diabetes mellitus, Mental emotional disorder, central obesity, dental and mouth health); (6) Infectious disease sub index that was performed by 3 indicator (pneumonia, children under five diarrhea, acute Respiratory Infectous disease); (7) Health Enviromental that was performed by 2 indicator ( sanitation, clean water access). All indicator has different weight considering a wide of exposure, outcome, urgent, visibility to reduce it ${ }^{13}$.

IKPS ( Special Index For Stunting ) is an index to describe five domains that represent the main indicator to combat stunting based on the INEY framework ( Investing Nutrition in Early Years 2018) of the world bank. (1) Health domain that was performed by 1 indicator (complete immunization); (2) Nutrition domain that was performed by 3 indicator (exclusive breastfeeding, dietary diversity, inadequate intake);(3) Food access domain that was performed by 1 indicator ( food insecurity experience scale ); (4) House living that was performed in 2 indicator ( safe drinking water, improved sanitation) ; (5) social protection that was performed by 1 indicator ( birth certificate) $)^{14}$.

Validity test using factor analysis to assess construct validity. The reliability analysis using coefficient Cronbach alpha was done to measure the reliability of indicator and index over time. Further analysis carried out by STATA using longitudinal panel data analysis with random effect models. These to assess determinant factors related to the index and to describe inequality of outcome that was observed. 


\section{RESULTS}

Based on the original global hunger index score calculation method that was adopted in the global hunger index in 34 sub-national levels ( GHI-SN) shows a mean of indicator in table 1 , with reliability and validity test. The reliability test was calculated within indicators over time. Otherwise, construct validity was used to the total variance of each indicator contribute to the score ${ }^{11}$.

Table 1. Validity and Reliability Indicator GHI-SN score

\begin{tabular}{|c|c|c|c|c|}
\hline & Mean & SD & $\begin{array}{l}\text { Reliability } \\
\text { Test }\end{array}$ & $\begin{array}{l}\text { Validity } \\
\text { Test }\end{array}$ \\
\hline & & & $\begin{array}{l}\text { Cronbach } \\
\text { Alfa }\end{array}$ & $\begin{array}{l}\text { Construct } \\
\text { Validity }\end{array}$ \\
\hline $\begin{array}{ll}\text { Prevalence } & \text { of } \\
\text { Undernourishment }\end{array}$ & & & 0.96 & \multirow{16}{*}{$56.31 \%$} \\
\hline 2007 & 20.41 & 5.30 & & \\
\hline 2010 & 19.84 & 5.98 & & \\
\hline 2013 & 21.67 & 5.62 & & \\
\hline 2018 & 19.28 & 4.58 & & \\
\hline Prevalence of Wasting & & & 0.63 & \\
\hline 2007 & 15.78 & 5.77 & & \\
\hline 2010 & 13.54 & 2.98 & & \\
\hline 2013 & 12.57 & 2.32 & & \\
\hline 2018 & 11.06 & 2.06 & & \\
\hline Prevalence of Stunting & & & 0.87 & \\
\hline 2007 & 36.88 & 6.57 & & \\
\hline 2010 & 35.55 & 7.37 & & \\
\hline 2013 & 38.22 & 6.09 & & \\
\hline 2018 & 30.36 & 5.35 & & \\
\hline $\begin{array}{l}\text { ChildrenMortalityRate } \\
\text { (percentage ) }\end{array}$ & & & 0.91 & \\
\hline 2007 & 5.72 & 1.78 & & \\
\hline 2012 & 5.07 & 2.28 & & \\
\hline 2017 & 6.27 & 1.87 & & \\
\hline
\end{tabular}

Table 1 shows a slight decrease in the prevalence of nutrition status in children during the last decade. The proportion of undernourishment, wasting, stunting tends to decline. Stunting is a major nutrition problem in children under five with a high prevalence of more than $30 \%$. However, there is progress achievement to reduce stunting in 2018. The reliability test between time showed that all indicator is reliable to be an indicator of measurement. And for indicator has a total of variance $56,31 \%$. In means, more than half of hunger can be explained with the indicator.

GHI score was classified following criteria: score >= 50.0 defined extremely alarming, 35.0-49.9 defined alarming, 20.00-34.9 defined serious level, 10.0-19.9 defined moderate and $<=9.9$ defined low ${ }^{4}$.

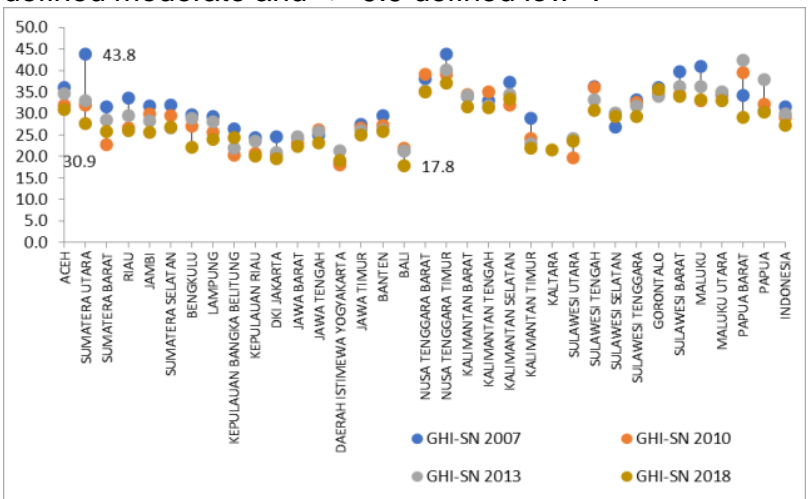

Figure 1. Global Hunger Index-Subnational ( GHI-SN ) in 2018 Indonesia

Figure 1 shows the GHI score was calculated and classify at the subnational level. Most of the province has the $\mathrm{GHI}$ score higher than $\mathrm{GHI}$ score in national levels. East Nusa Tenggara (Nusa Tenggara Timur (NTT)) has the highest score in GHI-SN. It means NTT has the level of hunger in severe condition (alarming) more than another province. Jogjakarta Province (Daerah Istimewa Yogyakarta (DIY)) has the lowest score of $<20 \%$ in GHISN since 2007. North Sumatra Province (Sumatra Utara) was shown has a significant toward progress combating hunger from 43.8 in 2007 to 30.9 in 2018.

Table 2. Validity, Reliabilty GHI-SN score, and relationship with IPKM ( Public Health Development Index ) and IKPS (Special Index Stuntiung Management)

\begin{tabular}{|c|c|c|c|c|c|}
\hline & Mean & SD & $\begin{array}{l}\text { Realibility Test } \\
\text { (AlfaCronbach) }\end{array}$ & $\begin{array}{l}\text { Correlation } \\
\text { Coefiicient }\end{array}$ & R Square \\
\hline \multicolumn{6}{|l|}{$\begin{array}{l}\text { Global Hunger Index Sub National (GHI- } \\
\text { SN) within the year }\end{array}$} \\
\hline 2007 & 31.50 & 6.3 & 0.96 & & \\
\hline 2010 & 29.08 & 6.1 & & & \\
\hline 2013 & 29.95 & 5.7 & & & \\
\hline-2018 & 27.38 & 5.2 & & & \\
\hline \multicolumn{6}{|l|}{$\begin{array}{l}\text { Global Hunger Index Sub National (GHI } \\
\text {-SN) Correlate between index }\end{array}$} \\
\hline \multicolumn{6}{|l|}{$\begin{array}{l}\text { GHI-SN 2013 } \\
\text { (reference) }\end{array}$} \\
\hline $\begin{array}{l}\text { IPKM } 2013 \\
\text { (Public Health Development Index ) for all }\end{array}$ & 0.53 & 0.04 & & -0.83 & 0.69 \\
\hline IPKM 2013 for children underfive & 0.60 & 0.04 & & -0.81 & 0.65 \\
\hline \multicolumn{6}{|l|}{ GHI-SN 2018 (reference) } \\
\hline IPKM 2018 for all & 0.63 & 0.04 & & -0.86 & 0.762 \\
\hline IPKM 2018 for children underfive & 0.66 & 0.06 & & -0.81 & 0.657 \\
\hline $\begin{array}{l}\text { IKPS } \\
\text { ( Special index for Stunting ) }\end{array}$ & 72.95 & 8.06 & & -0.67 & 0.440 \\
\hline
\end{tabular}

The reliability test shows the Cronbach alpha coefficient of more than 0,9 . It means the prevalence of child nutrition status and child mortality was stable and can involve to index. Table 3 shows that the level of hunger shows tend to decline during the last decade despite still at a serious level. GHI- SN shows a strong correlation with another index either IPKM and IKPS that has a more complex variable with correlation coefficient $>-0.8$ and -0.6 respectively. It means the highest score of hunger has a strong relationship with the lowest score in IPKM and IKPS. GHI 2018 can represent the public health 
development index in $60-75 \%$ and represent the program to reduce stunting in IKPS $44 \%$.Multivariate analysis was used to assess the determinant factors that related to the GHI-SN index and indicator that was involved ( table 3 ).

Table 3. The determinant of GHI-SN and each indicator that was involved

\begin{tabular}{|l|l|l|l|l|}
\hline Variable & $\mathbf{\rho}^{*}$ & $\begin{array}{l}\mathbf{R} \\
\text { Squared } \\
\text { (overall) }\end{array}$ & $\begin{array}{l}\text { Errors } \\
\text { (overall) }\end{array}$ & Coeficient \\
\hline GHI-SN & & $12.54 \%$ & 4.91 & \\
\hline Capita Expenditure & 0.00 & & & -4.05 \\
\hline $\begin{array}{l}\text { Prevalence of } \\
\text { undernourishment }\end{array}$ & & $11 \%$ & 4.34 & \\
\hline Capita expenditure & 0.06 & & & -3.59 \\
\hline Protein & 0.00 & & & -0.13 \\
\hline $\begin{array}{l}\text { Prevalence of } \\
\text { Stunting }\end{array}$ & & $31.90 \%$ & 3.73 & \\
\hline Capita expenditure & 0.00 & & & -6.02 \\
\hline Protein & 0.00 & & & -0.37 \\
\hline $\begin{array}{l}\text { Prevalence of } \\
\text { Wasting }\end{array}$ & & & & \\
\hline Capita expenditure & 0.00 & $17.89 \%$ & 1.95 & -4.89 \\
\hline $\begin{array}{l}\text { Prevalence of Child } \\
\text { Mortality }\end{array}$ & & & & \\
\hline Capita Expenditure & 0.00 & $25.33 \%$ & 1.36 & 1.36 \\
\hline Calorie & 0.00 & & & 0.01 \\
\hline Protein & 0.00 & & & -0.25 \\
\hline \multicolumn{2}{|l|}{ Analysis was } & & & \\
\hline
\end{tabular}

*) Analysis was carried out using linear regression to longitudinal panel data, random effect models. Panel:Subnational (province), Time :Year.

GHI-SN represents hunger and undernutrition and also the inequality of health at the sub-national level. The results show that the level of hunger was influenced by the socioeconomic status that was predicted by capita expenditure. These approximately $12.54 \%$ can be explained. Capita expenditure also related to the prevalence of wasting, approximately $17.89 \%$. The prevalence of stunting was determined by socioeconomic and protein consumption approximately $31.9 \%$. Otherwise, the prevalence of child mortality was predicted by $25 \%$ by socioeconomic status, calorie consumption, and protein.

\section{DISCUSSION}

Global Hunger Index is one of an international index that reflects the level of hunger worldwide. Based on the global concept of hunger, GHI was performed by three dimensions and four categories. The first dimension shows inadequate food supply that was performed by children's prevalence of undernourishment. This indicator is the lead of international hunger targets including the SDGs. Inadequate food supply is an important indicator of hunger that refers to both adults and children. The second dimension is child undernutrition that represents inadequate intake of food either quantity, quality, poor utilization due to infections or other illness or a combination of them. These caused by household food insecurity, inadequate maternal health or childcare practice or inadequate access to health services, safe water, and sanitation. The third dimension is child mortality that represents a serious consequence of hunger ${ }^{4}$.

The study shows that $\mathrm{GHI}$ at the sub-national level (GHI-SN) is valid and reliable for describing hunger and nutritional status at the sub-national level. The GHI index at a sub-national level can classify hunger levels in subnational regions. The results showed that the coefficient Cronbach alpha is great compared with another sub- national indicator. GHI-SN can be easily calculated and derived from the national survey report. The previous study that conducted in Ethiopia shows the subnational global hunger index to assessing progress in region level outcome ${ }^{15}$. However, the calculation of this index could be overestimated. It is influenced by the potential miss-value that we used to calculate it. Therefore to get valid measurement, a variable that was involved has to derive from the right sample method survey or complete data routine. That can represent a generalization of a population that was observed. Children's mortality rate value has been transformed in 100.000 life birth to adjusted.

However, the mortality not caused by a common form of illness related to nutrition is not suitable to measure the extent of hunger. Child mortality due to specific conditions Natural disasters, earthquakes, and war have to consider excluding the involved variable ${ }^{16}$. Another study showed that the GHI method's potential bias for accessing hunger because of child mortality is not only related to undernutrition. Therefore another method to measure hunger is a survey-based hunger method likes food access survey tools that measure food insecurity and behavior ${ }^{17}$. $\mathrm{GHI}$ can use to represent the outcome of childhood nutrition and health in general condition ${ }^{4}$.

The study shows that socioeconomic factors and sufficient daily intakes such as calories and proteins are the most predictors of nutrition in children under five. Otherwise, global hunger index and and the health outcome, in general, using mortality rate, socioeconomic also an important indicator to prediction. Furthermore, this study also supported the effectiveness of the convergence approach in controlling hunger and undernutrition in children from a multisectoral perspective. This study supported Unicef's conceptual framework and revealed that the quality of the home environment influenced growth and development in children ${ }^{18}$. A previous study carried out in America, Africa, and the Caucasus also shows the quality of the home environment concerning child performance ${ }^{19}$. Quality of the home environment plays an important role in the link between family socioeconomic and child development ${ }^{20}$.

Some research shows that socioeconomic levels are closely linked to hunger. The low socioeconomic (poor or quintile 1) status of the community has a negative impact on food availability in households. ${ }^{21-23}$. Previous ecological research has shown that the lower social and economically status was achieved in areas with a higher rate of hunger 24,25 . Similar research has been conducted in China, which positively contributes to reducing hunger by the socioeconomic factor in particular 26. Researchers recommend conducting a study to evaluate energy requirements to inform precision inputs for food and nutrition policymakers, supplemented by socioeconomic analysis $^{22}$.

\section{CONCLUSION}

Subnational hunger index can be used to subnational level as a valid and reliable index for assessing hunger and 
undernutrition in children under five, whereas this is the outcome of inequalities of health.

Conflict of Interest: All author declare that there was no conflict of interest associated with this paper

Acknowledgment: The author says thanks to National Health Research and the Development Department, Ministry of Health, Indonesia for all support. The author also thanks BPS to available data on the website and IKPS report.

\section{REFERENCE}

1. Akombi BJ, Chitekwe S, Sahle BW. Estimating the Double Burden of Malnutrition among Countries : A Meta-Analysis of Demographic and Health Surveys. 2019;1-11.

2. Development initiatives. Global Nutrition Report. Bristol, UK; 2018.

3. Webb P. Hunger and malnutrition in the 21 st century. 2018;2030:1-5.

4. Welthungerhilfe. Global hunger index ,Forced Migration and Hunger. Oktober201 ed. Dublin: Welthungerhilfe; 2018.

5. National Institute Health Research And Development $\mathrm{M}$ of $\mathrm{H}$. National Basic Health Research Survey Report (Riskesdas 2018). Jakarta, Indonesia: LBP Balitbangkes; 2019.

6. Hosseinpoor AR, Bergen $\mathrm{N}$, Barros AJD, Wong KLM, Boerma T, Victora CG. Monitoring subnational regional inequalities in health: measurement approaches and challenges. Int J Equity Health [Internet]. 2016; Available from: http://dx.doi.org/10.1186/s12939-016-0307-y

7. Health $M$ of, National Institute Health Research And Development M of H. Basic Health Survey, Riskesdas 2007. Jakarta, Indonesia; 2008.

8. Agency for Health Research and Development. Indonesia Basic Health Research 2013, Riskesdas2013. Jakarta, Indonesia; 2013.

9. Planning NA of F, Agency ISC, Ministry Of Health, USAID. 2017 Indonesia Demography and Health Survey Report. Jakarta, Indonesia; 2018.

10. Yahgmale F. Content validity and its estimation. J Med Edication. 2003;3:25-7.

11. Larsson H, Tegern M, Monnier A, Skoglund J. Content Validity Index and Intra- and Inter- Rater Reliability of a New Muscle Strength / Endurance Test Battery for Swedish Soldiers. 2015;1-13.

12. Strauss ME, Smith GT. NIH Public Access Construct Validity: Advances in Theory and Methodology. 2009;1-25.

13. Badan Litbang Kesehatan. Buku Indeks Pembangunan
Kesehatan Masyarakat (IPKM). Jakarta: Badan Litbang Kesehatan Kemenkes RI; 2018.

14. Statistik BP. Indeks Khusus Penanganan Stunting. Jakarta Indonesia; 2017.

15. Schmidt E, Dorosh P. A Sub-National Hunger Index for Ethiopia: Assessing Progress in Region-Level ESSP-II Discussion Paper 5 October 2009 A Sub-National Hunger Index for Ethiopia: Assessing Progress in Region-Level Outcomes. 2015;(May).

16. Biesalski HK. Methodological Review and Revision of the Global Hunger Index. 2015;(January).

17. Nigam AK. Improving Global Hunger Index. Agric Res [Internet]. 2018; Available from: https://doi.org/10.1007/s40003-018-0349-z

18. Engle P. Patrice Engle. Asian Develoment Rev. 1999;17(1):132-67.

19. Baharudin R, Luster T. Factors related to the quality of the home environment and children's achievement. J Fam Issues. 1998;19(4):375-403.

20. De Oliveira EA, Barros FC, Da Silva Anselmi LD, Piccinini CA. The quality of home environment in Brazil: An ecological model. J Child Fam Stud. 2006;15(5):631-42.

21. Haque A, Farzana FD, Sultana S, Raihan MJ, Rahman AS, Waid JL, et al. Factors associated with child hunger among food insecure households in Bangladesh. 2017;1-8.

22. Coghlan CM, Bhagwat SA. Going beyond hunger: Linking food supplies to global malnutrition Going beyond hunger: Linking food supplies to global malnutrition. Nor Geogr Tidsskr - Nor J Geogr [Internet]. 2019;0(0):1-7. Available from: https://doi.org/10.1080/00291951.2019.1569125

23. Grimaccia E, Naccarato A. Food Insecurity Individual Experience: A Comparison of Economic and Social Characteristics of the Most Vulnerable Groups in the World. Soc Indic Res [Internet]. 2018;(0123456789). Available from: https://doi.org/10.1007/s11205-018-1975-3

24. Loopstra R, Reeves A, Tarasuk V. The rise of hunger among low-income households: an analysis of the risks of food insecurity between 2004 and 2016 in a population-based study of UK adults. 2019;1-6.

25. Sands R, Hasegawa T, Fujimori S, Takahashi K, Masui T. Scenarios for the risk of hunger in the twenty-first century using Shared Socioeconomic Pathways Scenarios for the risk of hunger in the twenty- fi rst century using Shared Socioeconomic Pathways.

26. Islam MR. Hunger Reduction in China: An Analysis of Contextual Factors. 2016;0:1-16. 